Supporting Information

\title{
Instillation Technology for the Synthesis of a pH- Responsive Sodium Alginate/Biomass Charcoal Soil Conditioner for Controlled Release of Humic Acid and Soil Remediation
}

Weicong Wang, Keqi Qu, Xinrui Zhang, Min Teng, Zhanhua Huang*

Key Laboratory of Bio-based Material Science \& Technology, Ministry of Education, Northeast Forestry University, Harbin 150040, China

${ }^{*}$ To whom correspondence can be made

E-mail: huangzh1975@163.com (Z. H.) 


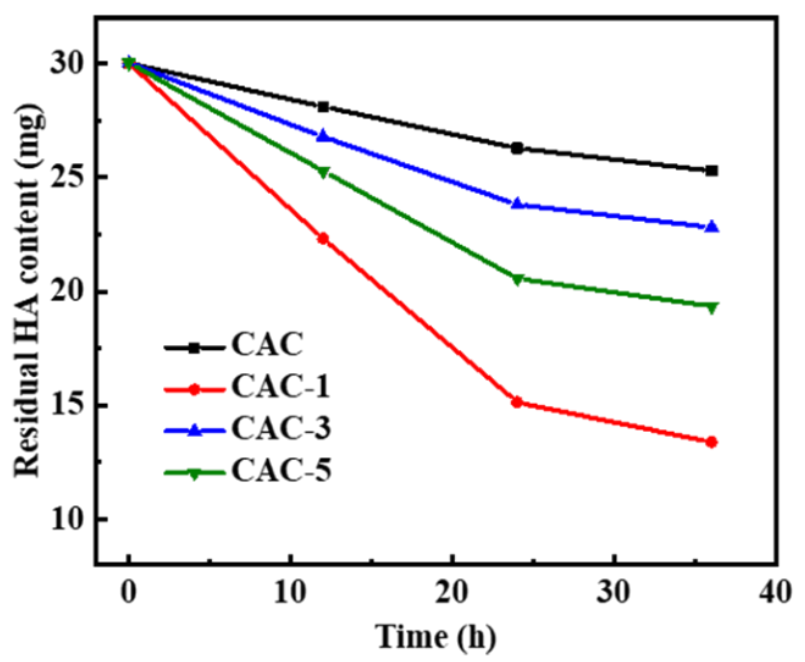

Fig. S1 Adsorption of HA by different CAC.

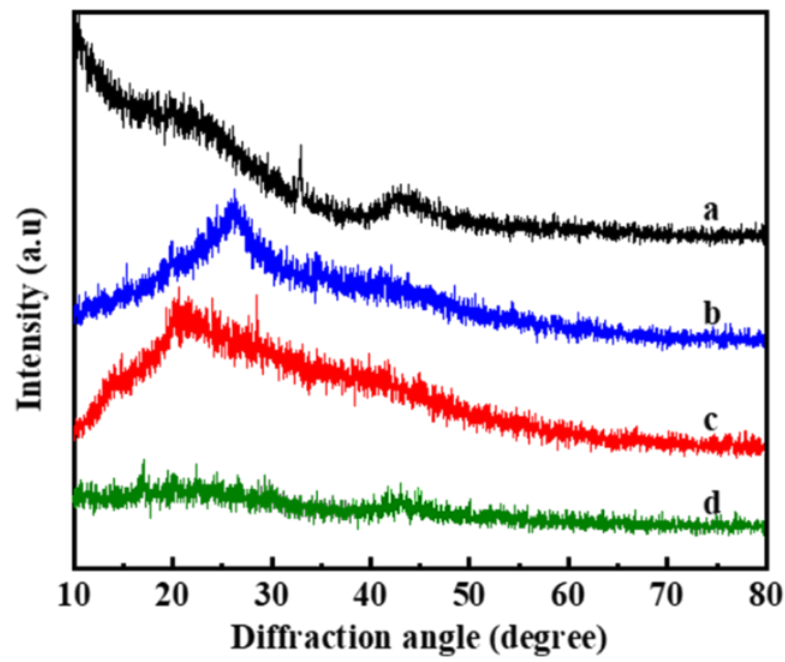

Fig. S2 XRD patterns of (a) CAC-1, (b) HA, (c) SA, and (d) CSGCH

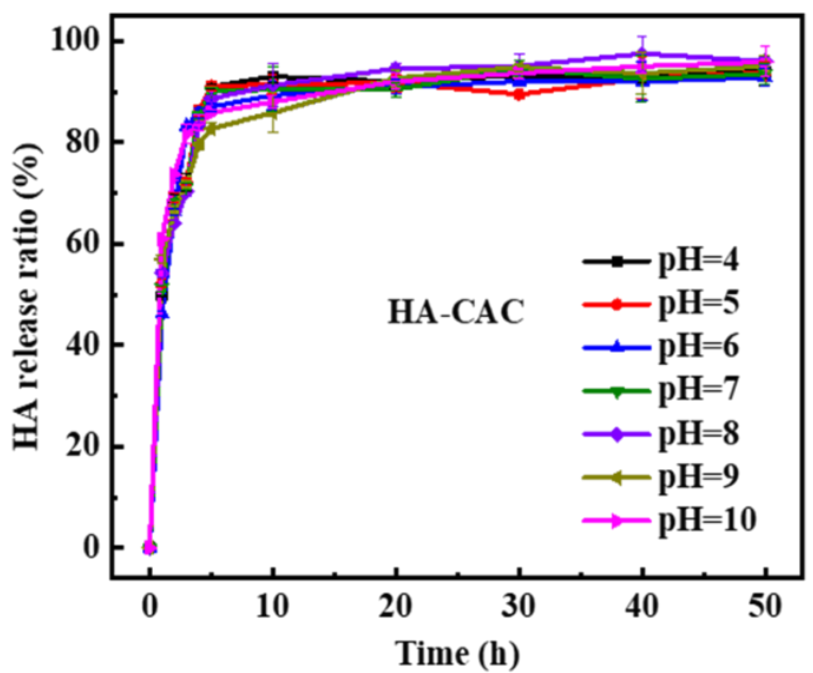

Fig. S3 Cumulative release of $\mathrm{HA}$ in $\mathrm{HA}-\mathrm{CAC}$ at $\mathrm{pH}$ values of 4.0 to 10.0. 

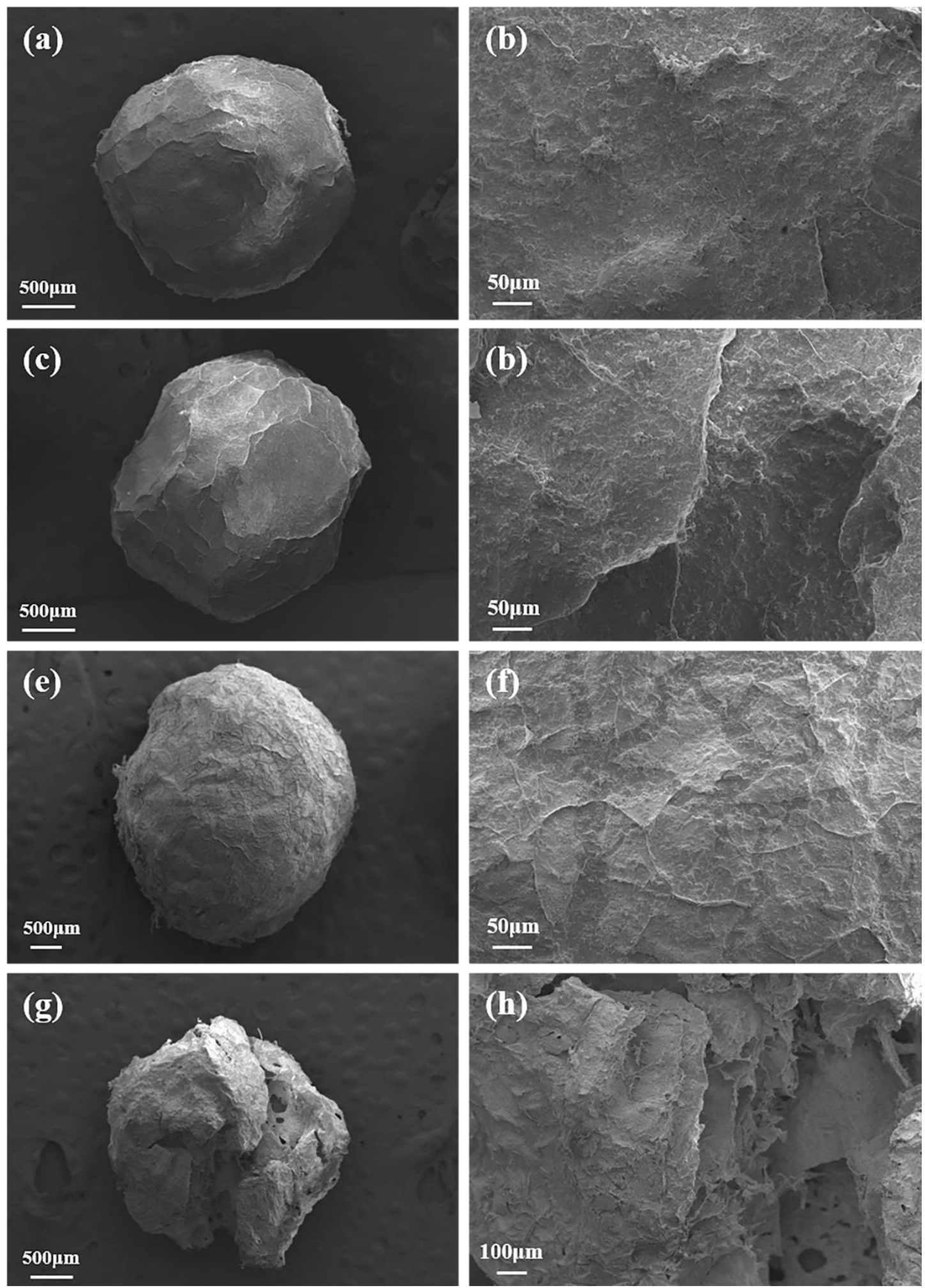

Fig. S4. Rupture states of gel spheres in buffer solutions of different $\mathrm{pH}$ values for $20 \mathrm{~h}(\mathrm{a}, \mathrm{b}) \mathrm{pH}=4$; (c, d) $\mathrm{pH}=5$; (e, f) $\mathrm{pH}=7$; $(\mathrm{g}, \mathrm{h}) \mathrm{pH}=9$. 
(a)

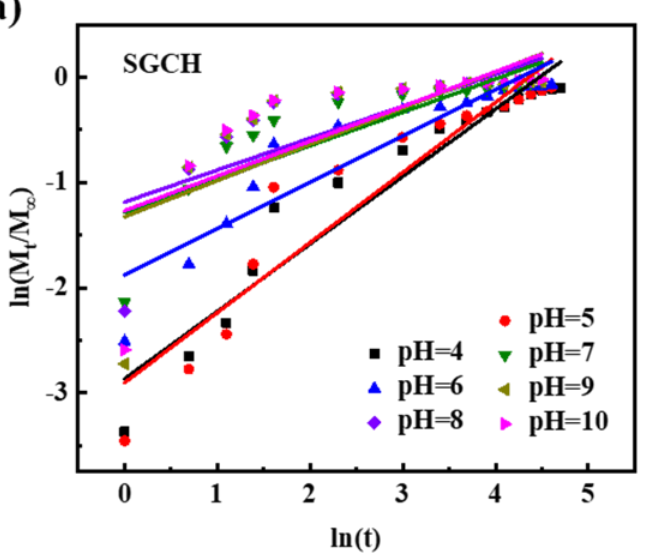

(c)

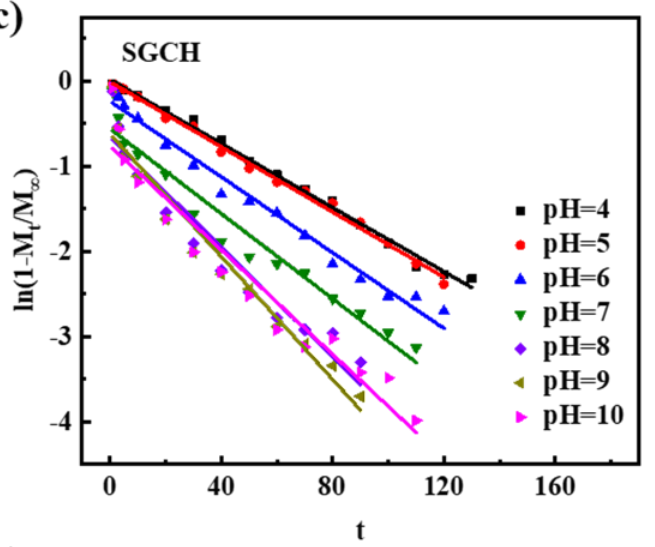

(e)

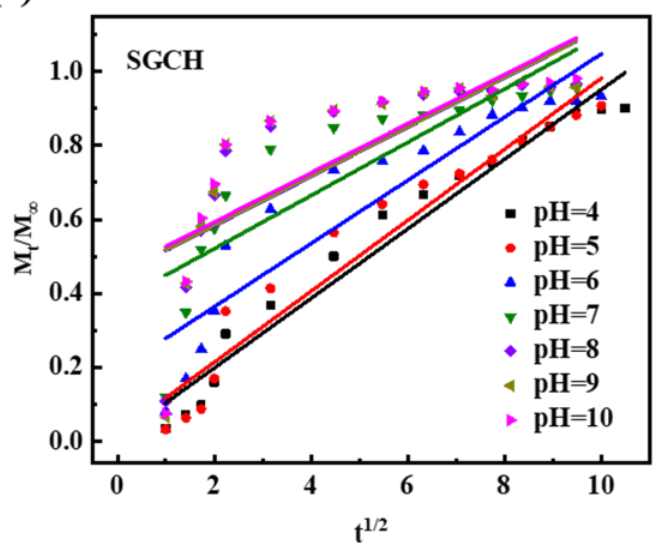

(b)

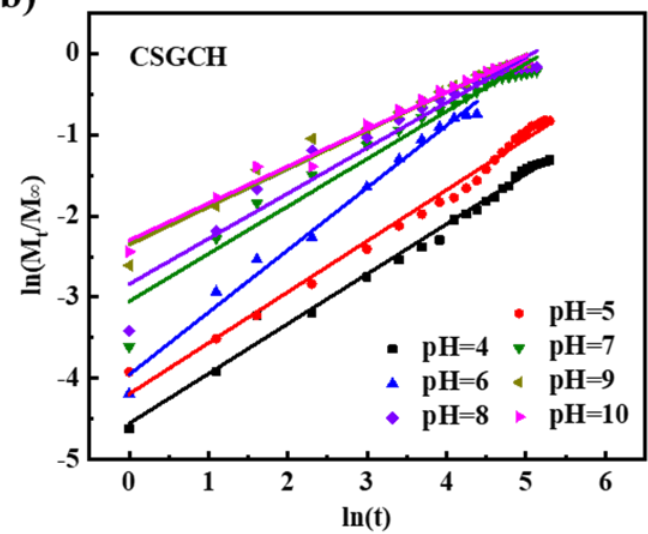

(d)

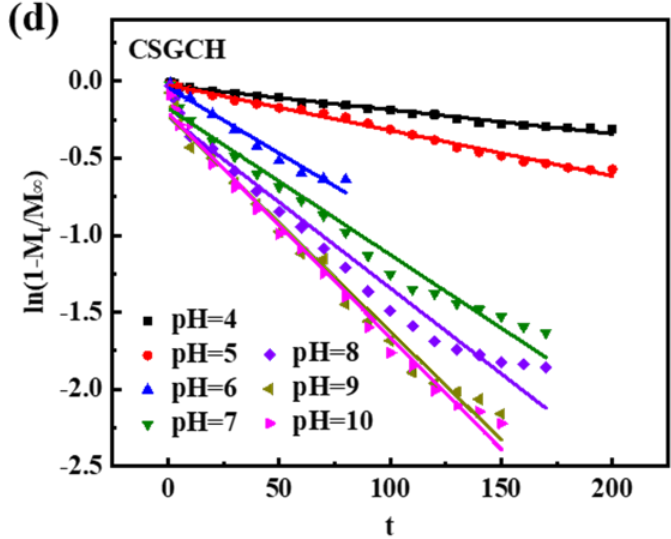

(f)

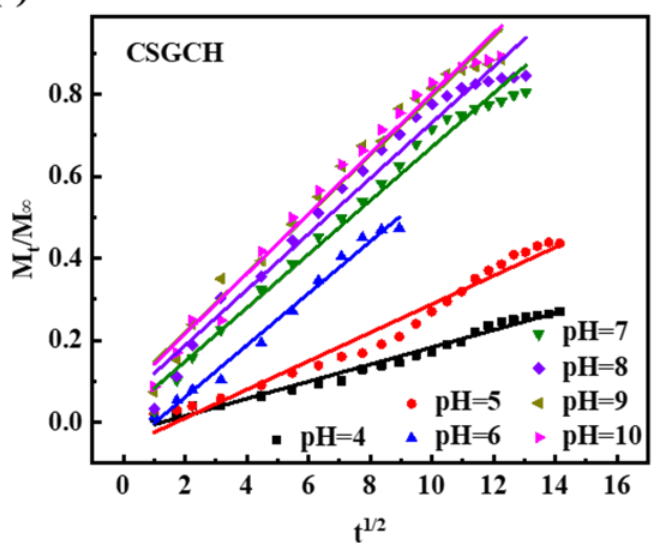

Fig. S5. Release kinetic model of $\mathrm{SGCH}$ and $\mathrm{CSGCH}$ gel spheres under different $\mathrm{pH}$ conditions 

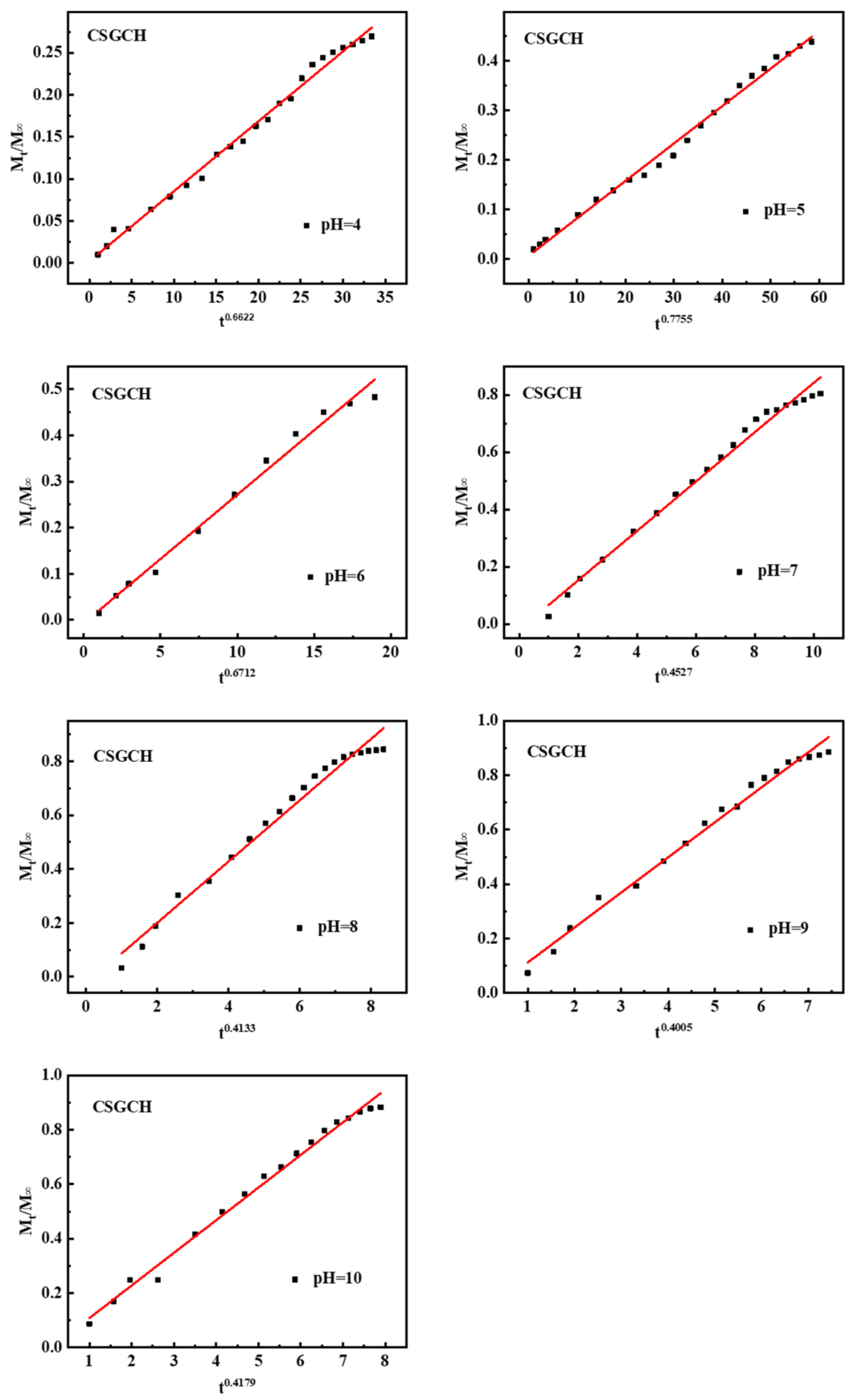

Fig. S6 Ritger-Peppas kinetic model of CSGCH gel spheres. 
Compressive strength

Gel spheres prepared were measured by micrometer for gel sphere diameter $\mathrm{d}(\mathrm{mm})$ and then tested for compressive strength using a universal material testing machine (HY-U230, Heng Wing Precision Instrument, China). The compressive strength of the gel spheres was shown in fig. S6. The addition of charcoal increased the compressive strength of the gel spheres by $0.052 \pm$ $0.01 \mathrm{Mpa}$. It may be because charcoal entered the three-dimensional lattice structure and cross-linked voids of the calcium alginate gel spheres, enhancing the denseness of their cross-linkages and thus causing an increase in mechanical properties.

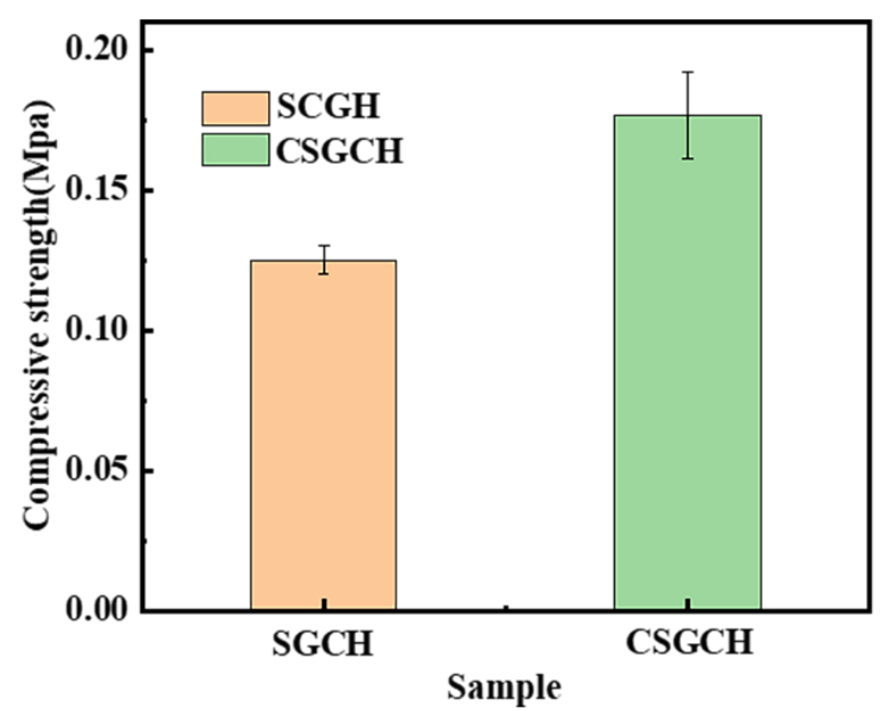

Fig. S7 Compressive strength of SGCH and CSGCH gel spheres. 

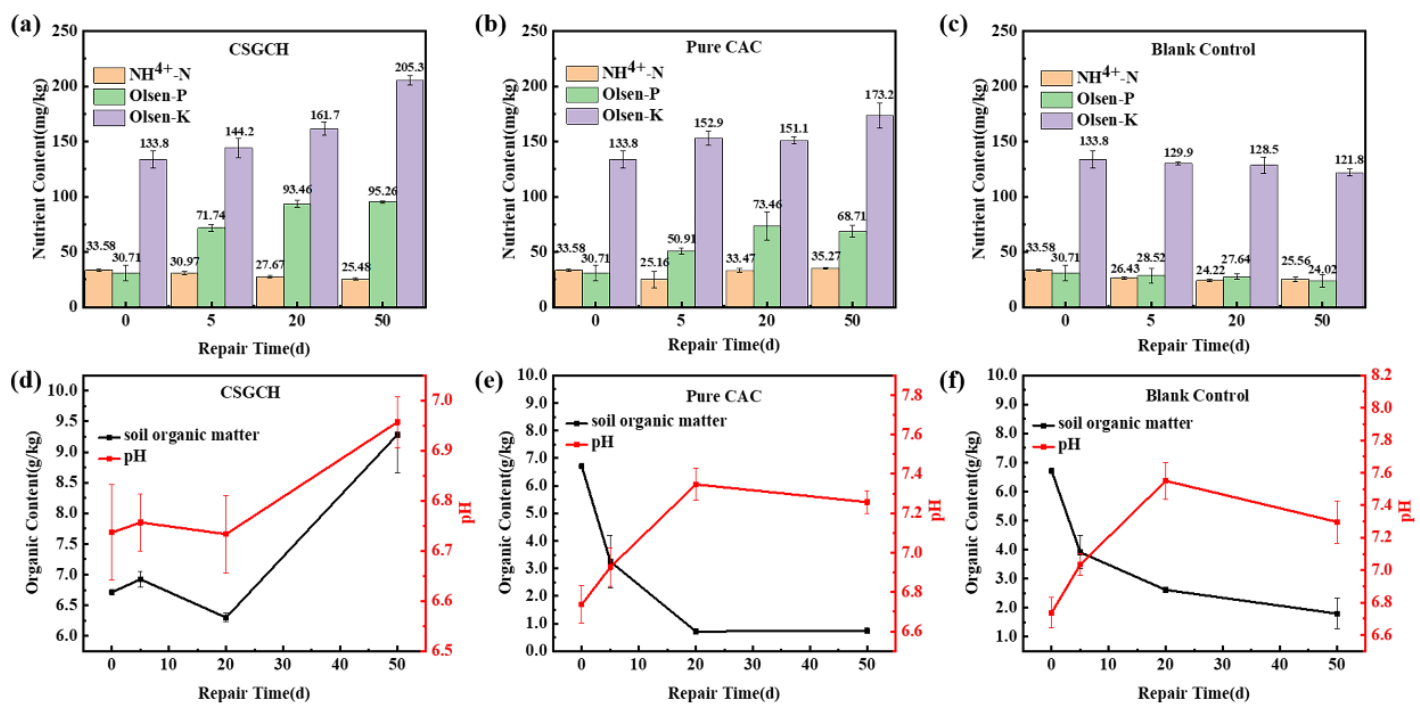

Fig. S8 Changes in $\mathrm{NH}^{4+}-\mathrm{N}$, Olsen-P, and Olsen- $\mathrm{K}$ in the red soil after three soil treatments (a) $\mathrm{CSGCH}$, (b) pure CAC, and (c) blank control; changes in organic matter and $\mathrm{pH}$ in red soil (d) $\mathrm{CSGCH}$, (e) pure CAC and (f) blank control.
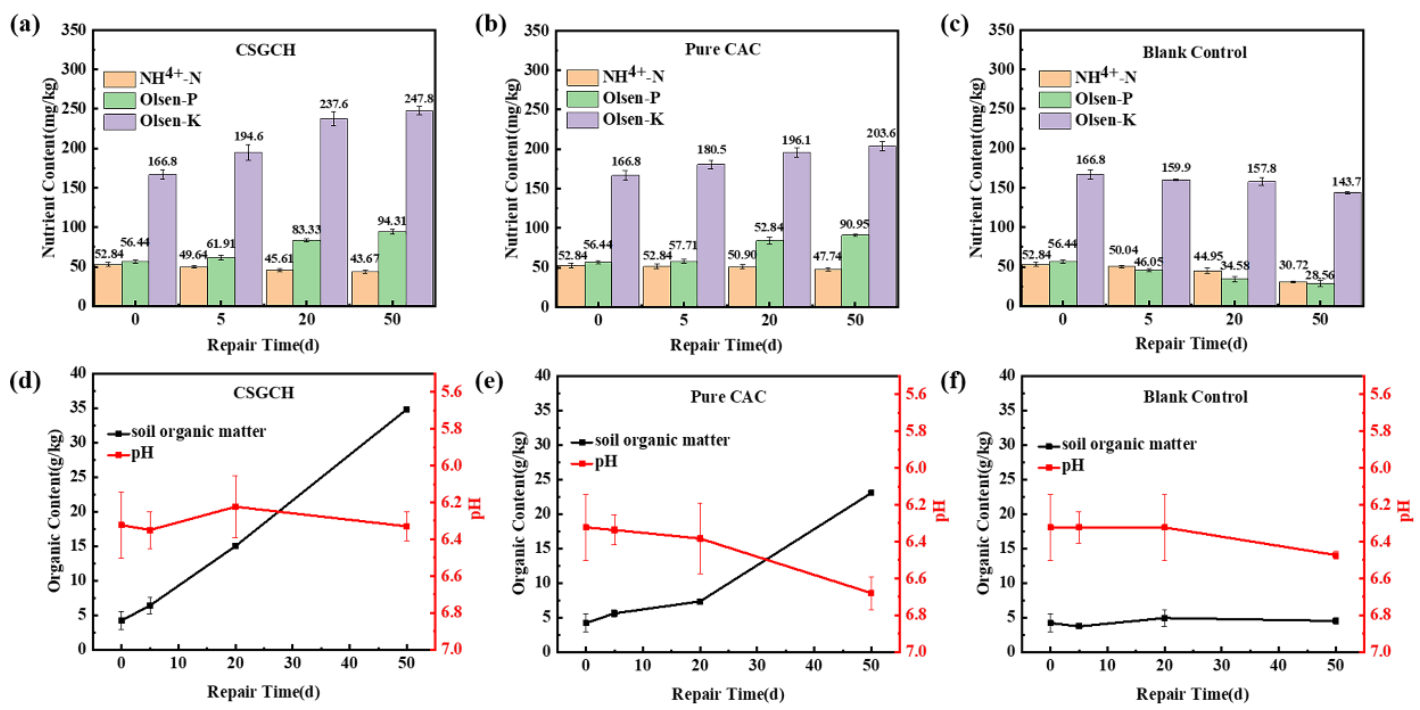

Fig. S9 Changes in $\mathrm{NH}^{4+}-\mathrm{N}$, Olsen-P, and Olsen-K in the natural soil after three soil treatments (a) $\mathrm{CSGCH}$, (b) pure CAC, and (c) blank control; changes in organic matter and $\mathrm{pH}$ in natural plantation soil (d) CSGCH, (e) pure CAC and (f) blank control. 
Table S1. Combination of variables by orthogonal experimental design for CSGCH Gel Sphere preparation.

\begin{tabular}{ccccc}
\hline Text number & $\mathrm{SA}(\mathrm{g})$ & $\mathrm{CAC}(\mathrm{g})$ & $\mathrm{CaCl}_{2}(\mathrm{~g})$ & Slow-release time $(\mathrm{h})$ \\
\hline 1 & 0.5 & 0.5 & 1 & 130 \\
2 & 0.5 & 1 & 3 & 120 \\
3 & 0.5 & 1.5 & 5 & 100 \\
4 & 1 & 0.5 & 5 & 140 \\
5 & 1 & 1 & 1 & 120 \\
6 & 1 & 1.5 & 3 & 110 \\
7 & 1.5 & 0.5 & 3 & 150 \\
8 & 1.5 & 1 & 5 & 170 \\
9 & 1.5 & 1.5 & 1 & \\
K1 & 350 & 420 & 380 & \\
K2 & 370 & 410 & 380 & \\
K3 & 450 & 340 & 410 & \\
k1 & 116.7 & 140 & 126.7 & \\
k2 & 123.3 & 136.7 & 126.7 & \\
k3 & 150 & 113.3 & 136.7 & \\
R & 33.3 & 26.7 & 10 & \\
\hline
\end{tabular}

Slow-release time was at $\mathrm{pH}=10.0$.

Table S2. Specific surface area (BET), mean pore diameter, and total pore volume of CAC.

\begin{tabular}{cccc}
\hline Sample & BET surface area $\left(\mathrm{m}^{2} / \mathrm{g}\right)$ & Total pore volume $\left(\mathrm{cm}^{3} / \mathrm{g}\right)$ & Mean pore diameter(nm) \\
\hline CAC & 916.93 & 0.909 & 3.7617 \\
CAC-1 & $2,673.53$ & 2.483 & 3.8176 \\
CAC-3 & $1,991.46$ & 1.128 & 2.1944 \\
CAC-5 & 3040.82 & 1.943 & 2.3644 \\
\hline
\end{tabular}


Table S3. The kinetic parameters of $\mathrm{HA}$ release from $\mathrm{CSGCH}$ and $\mathrm{SGCH}$ with $\mathrm{pH}$ values of $4.0 \sim 10.0$.

\begin{tabular}{|c|c|c|c|c|c|c|c|c|c|}
\hline \multirow[t]{3}{*}{ Samples } & \multicolumn{9}{|c|}{ Models } \\
\hline & \multicolumn{2}{|c|}{ Zero-order } & \multicolumn{2}{|c|}{ Frist-order } & \multicolumn{2}{|l|}{ Higuchi } & \multicolumn{3}{|c|}{ Ritger-peppas } \\
\hline & $\mathrm{k}$ & $\mathrm{R}^{2}$ & $\mathrm{k}$ & $\mathrm{R}^{2}$ & $\mathrm{k}$ & $\mathrm{R}^{2}$ & $\mathrm{k}$ & $\mathrm{n}$ & $\mathrm{R}^{2}$ \\
\hline CSGCH $(\mathrm{pH}=4)$ & 0.6135 & 0.9843 & 0.0016 & 0.9887 & 0.0209 & 0.9815 & 0.0084 & 0.6622 & 0.9921 \\
\hline $\operatorname{CSGCH}(\mathrm{pH}=5)$ & 0.6278 & 0.9921 & 0.0029 & 0.9863 & 0.0347 & 0.9676 & 0.0077 & 0.7755 & 0.9926 \\
\hline $\operatorname{CSGCH}(\mathrm{pH}=6)$ & 0.7669 & 0.9721 & 0.0085 & 0.9858 & 0.0633 & 0.9858 & 0.0274 & 0.6712 & 0.9869 \\
\hline $\operatorname{CSGCH}(\mathrm{pH}=7)$ & 0.5846 & 0.9742 & 0.0095 & 0.9571 & 0.0654 & 0.9833 & 0.0837 & 0.4528 & 0.9872 \\
\hline CSGCH $(\mathrm{pH}=8)$ & 0.5586 & 0.9625 & 0.0111 & 0.9443 & 0.0679 & 0.9671 & 0.1094 & 0.4133 & 0.9785 \\
\hline CSGCH (pH = 9) & 0.4684 & 0.9837 & 0.0141 & 0.9765 & 0.0721 & 0.9766 & 0.1257 & 0.4005 & 0.9877 \\
\hline $\operatorname{CSGCH}(\mathrm{pH}=10)$ & 0.4555 & 0.9889 & 0.0146 & 0.9857 & 0.0733 & 0.9793 & 0.1197 & 0.4179 & 0.9906 \\
\hline $\operatorname{SGCH}(p H=4)$ & 0.6409 & 0.9268 & 0.0189 & 0.9946 & 0.0942 & 0.9613 & 0.0525 & 0.6012 & 0.9827 \\
\hline $\mathrm{SGCH}(\mathrm{pH}=5)$ & 0.6666 & 0.8891 & 0.0191 & 0.9951 & 0.0961 & 0.9354 & 0.0595 & 0.5805 & 0.9806 \\
\hline $\mathrm{SGCH}(\mathrm{pH}=6)$ & 0.4406 & 0.8423 & 0.0222 & 0.9817 & 0.0856 & 0.8448 & 0.1538 & 0.3922 & 0.9709 \\
\hline $\mathrm{SGCH}(\mathrm{pH}=7)$ & 0.3171 & 0.6849 & 0.0249 & 0.9507 & 0.0719 & 0.7051 & 0.2936 & 0.2642 & 0.9267 \\
\hline $\mathrm{SGCH}(\mathrm{pH}=8)$ & 0.3057 & 0.5817 & 0.0323 & 0.9257 & 0.0668 & 0.5953 & 0.3489 & 0.2339 & 0.8732 \\
\hline SGCH (pH = 9) & 0.3443 & 0.5029 & 0.0361 & 0.9496 & 0.0666 & 0.5553 & 0.3496 & 0.2342 & 0.8413 \\
\hline $\mathrm{SGCH}(\mathrm{pH}=10)$ & 0.3307 & 0.5111 & 0.0306 & 0.9291 & 0.0665 & 0.5631 & 0.3575 & 0.2307 & 0.8445 \\
\hline
\end{tabular}

Table S4 shows the comparison of the maximum water holding capacity of the soil. Compared with previous studies by others, the CSGCH prepared in this study also had a better water-holding effect, with $1 \mathrm{wt} \%$ addition increasing the maximum water holding capacity of the soil by $31.19 \%$, which was better than other water retention agents based on sodium alginate. 
Table S4. Comparison of maximum water holding capacity of soils.

\begin{tabular}{|c|c|c|c|c|c|c|}
\hline Material & Soil type & $\begin{array}{l}\text { Water capacity of } \\
\text { the soil itself }(\%)\end{array}$ & $\begin{array}{l}\text { Maximum water } \\
\text { holding capacity } \\
\text { (After processing) }\end{array}$ & $\begin{array}{l}\text { content } \\
(\mathrm{wt} \%)\end{array}$ & $\begin{array}{l}\text { Incremental water } \\
\text { holding capacity } \\
(\%)\end{array}$ & Reference \\
\hline lignin/sodium alginate & - & $52.66 \%$ & $61.63 \%$ & 0.975 & $8.97 \%$ & 1 \\
\hline fenugreek galactomannan-borax hydrogel & Sand & $16.28 \%$ & $35.53 \%$ & 0.5 & $19.25 \%$ & 2 \\
\hline xanthan gum-g-polyacrylic acid/semi-coke & - & $30.33 \%$ & $50.66 \%$ & 0.5 & $20.33 \%$ & 3 \\
\hline Biogenic amorphous silica & Sand & - & - & 15 & $>25 \%$ & 4 \\
\hline Hemlock biochar & Sand & - & - & 1.0 & $13 \%$ & 5 \\
\hline Switchblade grass biochar & Sand & - & - & 1.0 & $30 \%$ & 5 \\
\hline Allobophora chlorotica & - & - & - & & $7-16 \%$ & 6 \\
\hline gap and capacity of carboxymethyl tamarind & - & $43.31 \%$ & $58.12 \%$ & 0.3 & $14.81 \%$ & 7 \\
\hline \multicolumn{7}{|l|}{ kernel gum (CMTKG) } \\
\hline Novel hydrogels were synthesized by grafting & - & $33.59 \%$ & $51.57 \%$ & 0.3 & $17.98 \%$ & 8 \\
\hline \multicolumn{7}{|l|}{ guar gum } \\
\hline CSGCH & Natural soil & $42.85 \%$ & $74.04 \%$ & 1.0 & $31.19 \%$ & This work \\
\hline
\end{tabular}


Table S5. Comparison of Soil Remediation

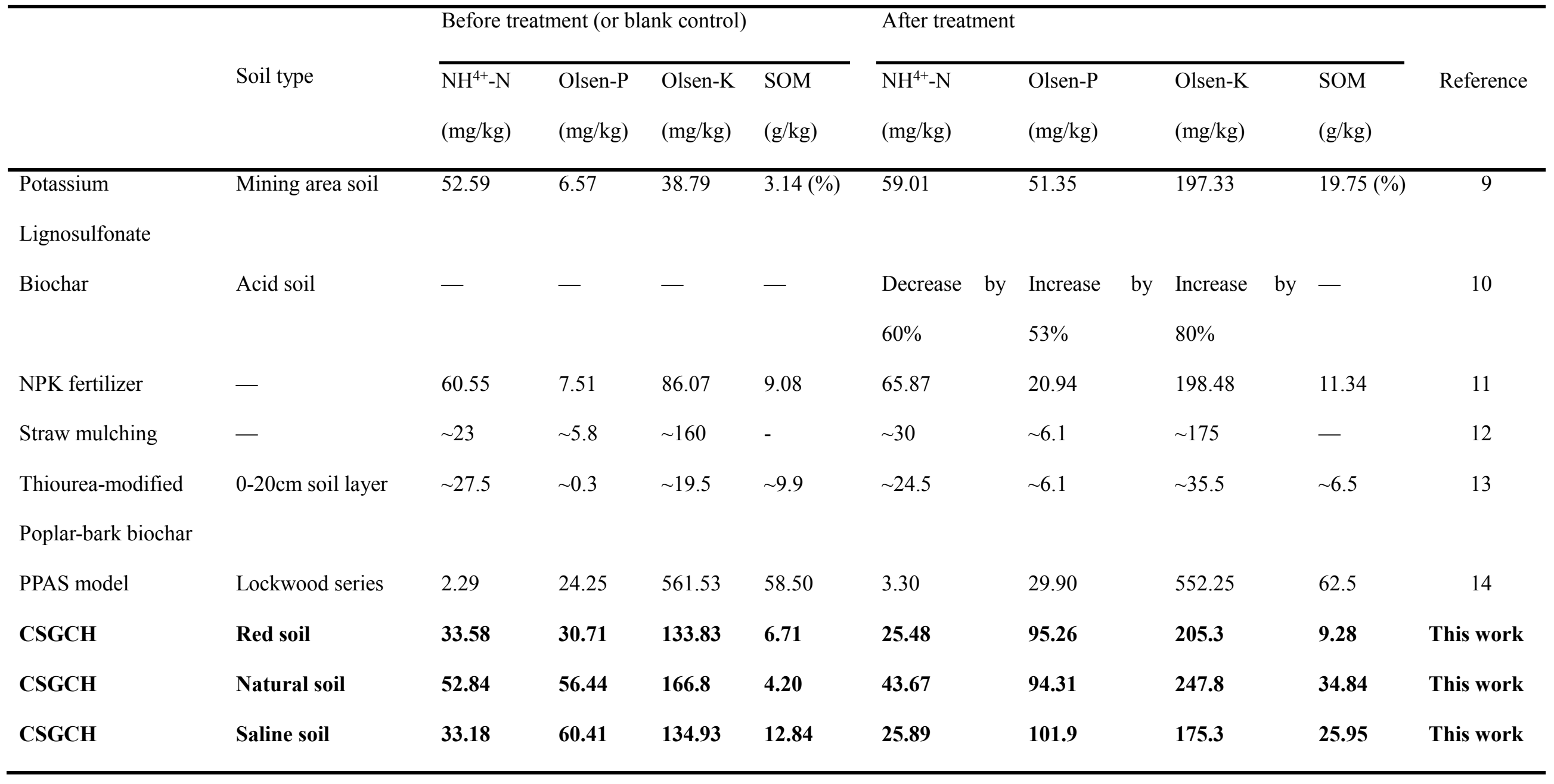


Table S5 compares the soil remediation effect of $\mathrm{CSGCH}$ gel spheres prepared in this study with other soil conditioners. Compared with the soil treated with crop return and biochar, $\mathrm{CSGCH}$ gel spheres had a better amelioration effect. At the same time, CSGCH could improve different types of soils better and significantly increased the content of nutrients and organic matter in the soil. It also proves that the soil amendment prepared in this study has a promising application.

\section{Reference}

1. Song, B.; Liang, H. X.; Sun, R. R.; Peng, P.; Jiang, Y.; She, D., Hydrogel synthesis based on lignin/sodium alginate and application in agriculture. Int. J. Biol. Macromol. 2020, 144, 219-230.

2. Liu, C. J.; Lei, F. H.; Li, P. F.; Jiang, J. X.; Wang, K., Borax crosslinked fenugreek galactomannan hydrogel as potential water-retaining agent in agriculture. Carbohydr. Polym. 2020, 236, 116100.

3. Liu, Y.; Zhu, Y. F.; Wang, Y. S.; Quan, Z. J.; Zong, L.; Wang, A. Q., Synthesis and application of eco-friendly superabsorbent composites based on xanthan gum and semi-coke. Int. J. Biol. Macromol. 2021, 179, 230-238.

4. Schaller, J.; Cramer, A.; Carminati, A.; Zarebanadkouki, M., Biogenic amorphous silica as main driver for plant available water in soils. Sci Rep. 2020, 10, 2424.

5. Yu, O. Y.; Harper, M.; Hoepfl, M.; Domermuth, D., Characterization of Biochar and Its Effects on the Water Holding Capacity of Loamy Sand Soil: Comparison of Hemlock Biochar and Switchblade Grass Biochar Characteristics. Environ Prog Sustain. 2017, 36, 1474-1479.

6. Hallam, J.; Hodson, M. E., Impact of different earthworm ecotypes on water stable aggregates and soil water holding capacity. Biol. Fertil. Soils. 2020, 56, 607-617.

7. Khushbu; Warkar, S. G.; Kumar, A., Synthesis and assessment of carboxymethyl tamarind kernel gum based novel superabsorbent hydrogels for agricultural applications. Polymer. 2019, 182, 121823.

8. Thombare, N.; Mishra, S.; Siddiqui, M. Z.; Jha, U.; Singh, D.; Mahajan, G. R., Design and development of guar gum based novel, superabsorbent and moisture retaining hydrogels for agricultural applications. Carbohydr. Polym. 2018, 185, 169- 
178.

9. Liu, Q. J.; Deng, Y.; Tang, J. P.; Chen, D.; Li, X.; Lin, Q. T.; Yin, G. C.; Zhang, M.; Hu, H. W., Potassium lignosulfonate as a washing agent for remediating lead and copper co-contaminated soils. Sci. Total Environ. 2019, 658, 836-842.

10. Rekasi, M.; Szili-Kovacs, T.; Takacs, T.; Bernhardt, B.; Puspan, I.; Kovacs, R.; Kutasi, J.; Draskovits, E.; Molnar, S.; Molnar, M.; Uzinger, N., Improving the fertility of sandy soils in the temperate region by combined biochar and microbial inoculant treatments. Arch Agron Soil. Sci. 2019, 65, 44-57.

11. Shen, W. S.; Xu, T. T.; Liu, J. J.; Huang, Q. R.; Gu, G. Y.; Zhong, W. H., Longterm application of organic manure changes abundance and composition of ammoniaoxidizing archaea in an acidic red soil. Soil Sci. Plant Nutr. 2015, 61, 620-628.

12. Chen, S. H.; Gao, R. C.; Xiang, X. L.; Yang, H. K.; Ma, H. L.; Zheng, T.; Xiao, Y.; Zhang, X.; Li, H.; Fan, G. Q.; Yu, Y., Straw mulching and nitrogen application altered ammonia oxidizers communities and improved soil quality in the alkaline purple soil of southwest China. Amb Express. 2021, 11.

13. Zhu, Y. F.; Ma, J.; Chen, F.; Yu, R. L.; Hu, G. R.; Zhang, S. L., Remediation of Soil Polluted with $\mathrm{Cd}$ in a Postmining Area Using Thiourea-Modified Biochar. Int. J. Env. Res. Pub. He. 2020, 17, 7654.

14. Hilimire, K.; Gliessman, S. R.; Muramoto, J., Soil fertility and crop growth under poultry/crop integration. Renew. Agr. Food Syst. 2013, 28, 173-182. 